Vol. 1 No. 1, Januari-Juni 2021: 37-47

\title{
ANALISIS PENGARUH KREATIF DAN INOVATIF DI DUNIA BISNIS KEWIRAUSAHAAN DALAM PERSPEKTIF EKONOMI ISLAM
}

\author{
Novita Mega Angel Virdianasari \\ Institut Agama Islam Negeri Ponorogo \\ Email:mega40845@gmail.com
}

\begin{abstract}
In writing this article, it aims to determine the effect of the benefits of creative and innovative ideas in running an entrepreneurial business based in an Islamic economy. The method in writing this article is to use descriptive analysis literature study to analyze the influence of creative and innovative ideas on the entrepreneurial world. The data collection technique is to look for secondary data obtained from sources relevant to the topic of discussion. By taking the title, taking advantage of this idea will have a great opportunity to face existing challenges and have great potential in the face of increasingly fierce business competition today. Because if you don't take advantage of this idea, the business you are running will be unable to compete with similar businesses and consumers will feel uninterested in simple products so that the business we run will experience a decrease in sales levels. Therefore, the existence of this idea will have a considerable influence in the world of economy and business so that consumers do not feel bored to buy and use these products. However, consumers can feel satisfied because they can use products with many benefits that consumers can take advantage.
\end{abstract}

Keywords: Entrepreneurship, Creative, Innovative, Islamic Economics

\begin{abstract}
Abstrak: Dalam penulisan artikel ini bertujuan untuk mengetahui pengaruh manfaat ide kreatif dan inovatif dalam menjalankan bisnis wirausaha yang berbasis dalam ekonomi Islam. Metode dalam penulisan artikel ini ialah dengan menggunakan studi pustaka analisis deskriptif untuk menganalisis pengaruh ide kreatif dan inovatif terhadap dunia usaha wirausaha. Teknik pengumpulan data adalah dengan mencari data sekunder yang diperoleh dari sumber yang relevan dengan topik pembahasan. Dengan mengambil gelar tersebut, karena dengan memanfaatkan ide tersebut akan memiliki peluang yang besar untuk menghadapi tantangan yang ada dan memiliki potensi yang besar dalam menghadapi persaingan bisnis yang semakin ketat saat ini. Karena jika tidak memanfaatkan ide ini maka bisnis yang dijalankan akan kalah bersaing dengan bisnis sejenis dan konsumen akan merasa tidak tertarik pada produk sederhana sehingga bisnis yang kita jalankan akan mengalami penurunan tingkat penjualan. Oleh karena itu, keberadaan ide ini akan memberikan pengaruh yang cukup besar dalam dunia ekonomi dan bisnis agar konsumen tidak merasa bosan untuk membeli dan menggunakan produk tersebut. Namun konsumen dapat merasa puas karena dapat menggunakan produk dengan banyak manfaat yang dapat dimanfaatkan konsumen.
\end{abstract}

Kata Kunci: Kewirausahaan, Kreatif, Inovatif, Ekonomi Islam 


\section{PENDAHULUAN}

Dalam dunia bisnis yang semakin berkembang dengan pesatnya, maka semakin banyak pula perusahaan yang berdiri sehingga terjadinya banyak persaingan yang semakin tajam di perusahaaan yang sejenis. Seiring dengan berkembangnya zaman yang semakin pesat maka seorang wirausaha harus untuk lebih kreatif dan inovatif dalam membuat produk sehingga bisnis yang dijalankan bisa berkembang seiring dengan banyaknya persaingan dengan menerapkan prinsip ekonomi dalam Islam. Sebuah usaha tanpa adanya kreativitasdan inovasi maka usaha yang dijalankan tidak akan pernah maju dan konsumen juga merasa bosan untuk membeli produk yang dihasilkan. Seorang wirausaha yang berperan dalam mengembangkan kekreatifan dan inovatif dalam membuat sebuah produk akan menjadi penggerak perekonomian yang cukup besar. Selain itu juga dengan banyaknya wirausaha akan meningkatkan pertumbuhan ekonomi dengan berkurangya angka pengangguran.

Menghadapi permasalahan dan tantangan dalam sebuah usaha tentunya seorang wirausaha harus memiliki karakter dan sikap kewirausahaan dalam menjalankan dan menciptakan produk dalam usahanya. Salah satu cara untuk menghadapi sebuah tantangan dalam usaha berbisnis yaitu adanya etika Islam dengan menerapkan ide kreatif dan inovatif sehingga akan berkreasi dalam menciptakan sebuah produk. Sesuatu yang berbeda dengan kreasi motif baru yang diciptakan dalam sebuah produk maka akan menjadi nilai tambah yang berkedudukan sebagai keunggulan produk. Dengan adanya keunggulan yang menjadi daya saing dalam berbisnis maka juga akan menciptakan peluang berwirausaha.

Oleh karena itu dalam penulisan artikel ini bertujuan untuk menganalisis mengenai pengaruh ide kreatif dan inovatis dalamusaha bisnis kewirausahaan dengan menerapkan ekonomi Islam. Selain itu juga dalam sebuah usaha tentunya mendapatkan keuntungan dan jugamenaikkan omset pendapatan dengan memperhatikan kepuasan pelanggan. Oleh karena itu untuk mendapatkan kepuasan pelanggan terhadap bisnis yang dijalankan maka dengan cara memberikan nilai tambah dengan adanya keunggulan terhadap produk dan juga layanan yang diberikan dengan cara yang baik sopan berdasarkan etika berbisnis. Dengan menganalisis maka penulis dapat memberikan sebuah judul dalam artikel yang berjudul "Pengaruh Ide Kreatif dan Inovatif di Dunia Bisnis Kewirausahaan dalam Ekonomi Islam”. 


\section{TINJAUAN LITERA TUR}

Kewirausahaan sendiri dapat dikatakan sebagai sesuatu kegiatan yang mempengaruhi suatu perencanaan bisnis. Bisnis sendiri tidak jauh dari kreatifitasdan inovatif yang dapat memberikan peluang dalam usaha sehingga akan memberikan keunggulan kewirausahaan. Hal tersebut sesuai dengan hasil penelitian Welly Mulyadi, Riswan E. Tarigan dan Andree E. Widjaja (2016) yang berjudul "pengaruh inovasi, kreativitas dan kepuasan konsumen terhadap keunggulan kompetitif "menunjukkan bahwa inovasi, kreativitas, serta kepuasan konsumen baik secara simultan maupun secara parsial mempunyai pengaruh positif dan signifikan terhadap keunggulan kompetitif.

Dalam kewirausahaan berbisnis dengan adanya model desain dalam menghasilkan produk makaakan memberikan dampak positif dengan adanya keunggulan sehingga dapatbersaing dengan usaha yang lainnya. Hal tersebut sesuai dengan penelitian Muhammad Mansyur (2013 )yang berjudul "Pengaruh desain dan Kualitas produk terhadap Keunggulan Bersaing" menunjukkan bahwa desain dan kualitas produk berpengaruh positif secara simultan dan parsial terhadap keunggulan bersaing. Oleh karena itu dengan adanya ide kreatif dan inovatif akan memberikan keunggulan dalam berbisnis dengan kualitas yang baik dan terjamin sehingga konsumen akan merasa puas. Kualitas produk tergolong pada kategori baik danberpengaruh positif secara signifikan dengan arah positif terhadap keunggulan bersaing.

Dalam berwirausaha adanya ide yang menjadi keunggulan dalammenciptakan produk dengan berbagai model masa kini sehingga konsumen tidak akan bosan. Sesuai dengan hasilpenelitian Disma Rangga (2013) yang berjudul "Pengaruh Kreativitas Produk dan Inovasi Produk terhadap keunggulan bersaing” menunjukkan bahwa secara bersama sama variable kreativitas produk dan inovasi produk memberikan kontribusi atau pengaruh terhadap keunggulan bersaing. Tetapi kreativitas produk berpengaruh positif namun tidak signifikan karena masih ada faktor lain diluar kreativitas produk yang lebih mempengaruhi seperti inovasi produk,lokasi yang strategi sehingga akan menarik perhatian dan berpengaruh terhadap orientasi pasar serta orientasi teknologi (Rika, 2018).

Dalam jiwa kewirausahaan adanya sifat pemberani dan pantang menyerah sehingga tidak mudah putus asa dalam menjalankan bisnisnya meskipun terdapat masalah yang dihadapi. Tentu seorang wirausaha dengan adanya permasalahan dapat dijadikan sebagai pembelajaran agar langkah kedepannya biasa lebih baik lagi dengan cara mengevalusi usaha yang telah dilakukan. Menurut Jong and Wennekers (2008) 
menyatakan bahwa kewirausahaan dapat didefinisikan sebagai pengambilan resiko untuk menjalankan usaha dengan memanfaatkan peluang untuk menciptakan usaha baru dengan adanya ide kreatif dan inovatif dalam mengahadapi tantangan persaingan. Seorang wirausaha harus memiliki ide baru yang dihasilkan dari sesuatu kreativitas yang membawa inovasi terhadap usahanya.

Kewirausahaan tentu adanya pinsip Islam yang yang bersumber pada Al Quran yang bertujuan untuk mecari keuntungan namun disisi lain mencari kebahagiaan didunia dan diakhirat kelak. Menurut Nurfaqih dan Fahmi, (2018) menyatakan bahwa dalama nilai nilai Islam berdasarkan konsep kewirausahaan terdapat empat bentuk nilai. Pertama, Tauhid atau keimanan terhadap Allah SWT sebagai Tuhan Yang Maha Esa. Kedua, nilai keadilan dimana kegiatan didasarkan pada perasaan sama rata dan sama rata. Ketiga, Nilai hasil kegiatan tersebut yang memberikan hasil para pelaku pada saat kegiata tersebut berlangsung. Keempat, Nilai sukarela (ikhlas). Dimana dalam proses berwirausaha tentu seleuh kegiatan yang berdasar pada nilai keikhlasan dan berserah diri kepada Allah SWT akan menimbulkan hasil yang baik.

Di zaman sekarang semakinbanyak pesaing usaha yang sama maka akan menjadi tantangan dalam berwirausaha. Sesuai dengan penelitian Larsen, P and Lewis, A, (2007) menyatakan bahwa salah satu karakter yang penting dalam berwirausaha adalah kemampuan berinovasi. Sifat kepribadian seorang wirausaha mempunyai pengaruh positif terhadap prestasi perusahaan dengan cara menggunakan ide yang dimiliki untuk memproduksi produk yang akan dijual. Dengan adanya inovasi maka desain maupun model dalam produk dapat berubah ubah, mengingat kebutuhan, keinginan dan permintaan konsumen yang berubah ubah pula. Hal tersebut juga harus sesuai dengan model perkembangan zaman yang semakin beragam sehingga tidak kalah saing dengan usaha lain.

\section{METODE PENELITIAN}

Penelitian adalah suatu kegiatan seseorang yang bertujuan untuk memecahkan suatu persoalan masalah berdasarkan fakta yang ada dengan menggunakan teori yang relevan. Berdasarkan objeknya dengan melakukan suatu penelitian langkah akhir yang dilakukan ialah mengambil kesimpulan berdasarkan fakta yang ada untuk menemukan jawaban dari suatu permasalahan yang ditemukan. Dalam penelitian ini jenis data yang digunakan adalah data kualitatif, yaitu data yang tidak dapat dinyatakan dalam bentuk angka-angka. Instrumen 


\section{Niqosiya: Journal of Economics and Business Research}

Vol. 1 No. 1, Januari-Juni 2021: 37-47

penelitian atau alat pengumpul data yang akan digunakan dalam penelitian ini adalah data kualitatif dengan teknik pengumpulan data untuk memperoleh informasi dan apa masalah yang dibahas dengan menggunakan teknik tersebut.

Metode dalam penulisan artikel ini denganmenggunakan kajian pusataka dengan analisis deskriptif. Dimana analisis data merupakan tahapan proses meneliti data sudah ada yang ada yang bersumber dari buku, jurnal maupun skripsi yang relevan dengan teman yang diangkat. Dengan menggunakan metode kajian pustaka maka langkah yang dilakukan peneliti ialah mencari materi, membaca dan menganalisis teori yang ada untuk dijadikan referensi dalam pembuatan atikel ini. Teknik dalam pengumpulan data yang digunakan yaitu dengan cara mencari datasekunder yang diperoleh dari sumber sumber yang relevan dengan topik pembahasan. Pengumpulan data berisitentang teknik analisis data yang digunakan berdasarkan data yang diperoleh untuk digunakan dalam analisis pengaruh ide kreatif dan inovatif dalam kewirausahaan.

\section{HASIL DAN PEMBAHASAN}

Mitra dalam kegiatan usaha kewirausahaan adalah para usaha UMKM yang berdasarkan kemampuan terhadap jiwa kewirausahaan melalui ide kreatifdan inovatif. Tabel berikut ini menyajikan jumlah pelaku usaha berdasarkan jenis kelamin.

Tabel 1. Pelaku Usaha Berdasarkan Jenis Kelamin

\begin{tabular}{ccc}
\hline Usia & \multicolumn{2}{c}{ Jenis Kelamin } \\
\cline { 2 - 3 } & Laki laki & Perempuan \\
\hline 20 & 5 & 5 \\
\hline 30 & 19 & 21 \\
\hline 40 & 14 & 16 \\
\hline Jumlah & 38 & 42 \\
\hline
\end{tabular}

Dari tabel 1 memperlihatkan bahwa jumlah pelaku usaha UMKM yang berjenis kelamin perempuan lebih banyak daripada yang berjenis kelamin laki laki dengan rentang perbedaan yang tidak terlalu jauh. Berdasarkan pada tabel jiwa kewirausahaan dengan adanya kemampuan kreatif dan inovatif dalam menghasilkan suatu produk tidak membatasi jenis kelamin dan usia. Pada dasarnya wirausaha adalah kemampuan seorang individu dalam maupun luar organisasi untuk menemukan dan menciptakan peluang ekonomi yang baru (Suliyanto, 2012). Dengan adanya wirausaha yang semakin banyak maka akan berpengaruh terhadap tingkat pengangguran yang semakin menurun. 
Sehingga dengan adaya haltersebut maka tingkat pertumbuhan ekonomi akan meningkat sehingga masyarakat merasa sejahtera dengan tidak adanya kesenjangan.

Seiring berkembangnya zaman, maka semakin pula mengalamiperubahan. Oleh karena itu, dalam meraih kesuksesan perlu adanya ide kreatif dan inovatif dalam berwirausaha. Dalam berbisnis seseorang yang belum pernah mencoba produk yang dihasilkan oleh wirausaha maka orang tersebut tidak layak untuk menyimpulkan hasil produk tersebut. Sehingga sebaiknyaseseorang sebelum menyimpulkan terhadap suatu produk maka terlebih dahulu mencoba untuk membuktikan kemudian baru menyimpulkan. Untuk bisnis menjadi maju dalam prestatif seorang pengusaha harus memiliki motivasi yang tinggi, inovatif dan memiliki keinginan untuk berkembang (Anwar,2014). Pada dasarnya seorang wirausaha juga memiliki visi, misi dan tujuan yang jelas dalam berbisnis. Dengan adanya hal tersebut maka mempunyai langkah yang akan dituju sehingga dapat mengetahui langkah apa yang harus dilakukan sesuai dengan rencana. Oleh karena itu dengan adanya visi maka dapat melihat gambaran masa depan untuk diwujudkan dan dengan adanya misi kita dapat mengetahui langkah apa saja yang dilakukan agar visi dan tujuan bisa tercapai. Jadi produsen dalam berusaha lebih menyukai prinsip kerja sama dengan perusahaan lain dengan cara berbagi ide satu sama lain agar idenya bisa bertambah. Pada umumnya suatu usaha lebih menyukai hubungan kerja sama dalam hal berbisnis yang bertujuan untuk mendapatkan keuntungan kedua belah pihak dan juga bisa saling melengkapi satu sama lain dengan cara kerjasama untuk meningkatkan peluang dan berwirausaha.

Dalam kehidupan sehari hari perekonomian menjadi salah satu kebutuhan yang mendasar bagi setiap manusia untuk bisa hidup dan berkembang (Anwar, 20114), karena tanpa adanya ekonomi kehidupan akan terganggu. Perekonomian juga terdapat prinsip Islam yang menjelaskan mengenai masalah ekonomi kehidupan manusia yang berlandaskan pada etika Islam yang bersumber dari Al Quran dan Hadist. Dengan penerapan islam dalam masalah ekonomi wirausaha tentu akan terciptanya kejujuran dan keadilan sehingga tidak ada salah satu pihak yang merasa dirugikan. Salah satu penerapan ekonomi Islam dalam perekonomian berwirausaha yaitu dalam hal transaksi yang tidak mengandung unsure riba dan menghindari transaksi batil (Dwi, 2020). Dimana perbuatan seorang wirausaha yang sesuai dengan syariat Islam yaitu dengen memperjualbelikan barang yang jelas wujudnya dan diserahkan kepada pembeli secara langsung pada saat akad. Selain itu juga dalam proses bertransaksi tidak adanya unsur penipuan sehingga 


\section{Niqosiya: Journal of Economics and Business Research}

Vol. 1 No. 1, Januari-Juni 2021: 37-47

tidak adanya unsure yang dirugikan.

Seiring berkembangnya zaman, maka semakin pula mengalami perubahan. Oleh karena itu, dalam meraih kesuksesan perlu adanya ide kreatif dan inovatif dalam berwirausaha. Dalam berbisnis seseorang yang belum pernah mencoba produk yang dihasilkan oleh wirausaha maka orang tersebut tidak layak untuk menyimpulkan hasil produk tersebut. Sehingga sebaiknya seseorang sebelum menyimpulkan terhadap suatu produk maka terlebih dahulu mencoba untuk membuktikan kemudian baru menyimpulkan. Untuk bisnis menjadi maju dalam prestatif seorang pengusaha harus memiliki motivasi yang tinggi, inovatif dan memiliki keinginan untuk berkembang. Pada dasarnya seorangwirausaha juga memiliki visi, misi dan tujuan yang jelas dalam berbisnis (Alma, 2009). Dengan adanya hal tersebut maka mempunyai langkah yang akan dituju sehingga dapat mengetahui langkah apa yang harus dilakukan sesuai dengan rencana. Olehkarena itu dengan adanya visi maka dapat melihat gambaran masa depan untuk diwujudkan dan dengan adanya misi kita dapat mengetahui langkah apa saja yang dilakukan agar visi dan tujuan bisa tercapai. Jadi produsen dalam berusaha lebih menyukai prinsip kerja sama dengan perusahaan lain dengan cara berbagi ide satu sama lain agar idenya bisa bertambah. Pada umumnya suatu usaha lebih menyukai hubungan kerja sama dalam hal berbisnis yang bertujuan untuk mendapatkan keuntungan kedua belah pihak dan juga bisa saling melengkapi satu sama lain dengan cara kerjasama untuk meningkatkan peluang dan berwirausaha.

Selain itu dalam bisnis fashion juga sangat rentang terhadap model, trenddan gaya hidup yang selalu berubah sesuai dengan berkembangnya zaman saat ini dan selera para konsumen. Oleh karena itu seorang produsen harus mengetahui model dan trend terbaru di lingkup masyarakat agar produk yang dibuat dapat laku. Dengan ide kreatif dan inovatif akan membangun sebuah usahayang mampu bertahan lama dengan model dan trend terbaru yang bisa melayani kebutuhan konsumen. Oleh karena itu, dalam berbisnis di dunia fashion tidak pernah hilang tetapi selalu membutuhkan inovasi dan imajinasi yang luas untuk menghasilkan produk fashion model terbaru agar tidak kalah saing dengan industri lainnya. Dan tentunya dengan produk yang kreatif juga akan berpengaruh terhadap pendapatan dalam berwirausaha karena tingginya tingkat kekreatifan maka harga suatu produk akan semakin mahal pula. Dan sebaliknya jika model suatu produk yang standart tentu harga barang tersebut lebih murah daripada produk yang memiliki model terbaru. 
Dalam berwirausaha tingkat kreativitas akan sangat mempengaruhi dalam kemajuan bisnisnya. Selain itu keberhasilan seorang wirausaha dapat dilakukan dengan cara memanfaatkan ide kreatif dan inovatif dalam menjalankan kegiatan bisnisnya dan juga adanya penerapan etika bisnis berwirausaha yang baik. Dengan adanya etika berbisnis sesuai ekonomi Islam tentu juga akan berpengaruh terhadap kemajuan suatu usaha, karena antara kedua belah pihak saling suka sama suka sehingga tidak ada yang dirugikan. Oleh karena itu seorang wirausaha pada prinsipnya memiliki ide kreatif dan inovatif sehingga memiliki daya cipta dengan model baru sehingga dapatbersaing dengan bisnis lainnya. Karena pada hakikatnya setiap model dalam dunia wirausaha sangat berbeda dari perkembangan zaman dan canggihnya teknologi modern saat ini.

Kreatif merupakan suatu ide untuk menciptakan suatu produk yang berbeda dengan sebelumnya ataulainnya. Sedangkan, inovasi adalah suatu kegiatan untuk menciptakan dan mengembangkan dengan ide atau gagasan baru yang belum ada pada sebelumnya. Jadi kedua kata tersebut saling berkaitan terutama dalam pengembangan suatu bisnis. Kreatif disini juga salah satu proses yang membantu dalam mencetuskan gagasan, sedangkan inovasi juga penerapan praktis dari gagasan. Diibaratkan dengan kreativitas sebagai bahan bakunya dan inovasi sebagai hasil yang komersial.Kemampuan kreativitas seseorang dapat ditingkatkan dan dikembangkan, akan tetapi kemampuan ini akan berbeda antara satu orang dengan orang lainnya. Oleh karena itu seorang wirausaha dengan memanfaatkan ide tersebutakan menciptakan suatu produk yang unggul dengan desain berbeda denganyang lainnya. Salah satu ide kreatif dan inovatif yaitu dengan cara daur ulang. Dimana daur ulang merupakan suatukegiatan yang memanfaat barang yang tidak terpakai lagi dengan cara melakukanberbagai tahap pengolahan seperti mengolah kain perca menjadi suatu produk.

Dalam dunia bisnis pasti adanya persaingan yang menjadi tantangan dalam suatu usaha. Untuk menghadapi persaingan tersebut dibutuhkan ide kreatif dan inovatif sehingga menghasilkan produk yang unggul dibandingkan dengan produk yang standart. Dengan memanfaatkan ide kreatif dan inovatif maka akan berpengaruh dalam strategi untuk menaikkan omzet pendapatan dan berpengaruh terhadap pemasaran kewirausahaan serta dapat menarik konsumen untuk ingin membeli produk tersebut (Riansyah,2017). Dengan adanya daya kreatifitas maka akan menghasilkan produk yang bervariasi, memiliki desain yang menarik, memiliki motif produk yang banyak dan adanya promosi dan pengemasan produk yang menarik. Selain itu juga dengan ide kreatif dan inovatif 


\section{Niqosiya: Journal of Economics and Business Research}

Vol. 1 No. 1, Januari-Juni 2021: 37-47

akan berpengaruh besar untuk mengembangkan dan memajukan suatu usaha. Karena pada umumnya konsumen lebih suka produk produk baru dan cenderung yang lebih unik. Tanpa adanya kreatifitas makausaha produk yang dihasilkan kurang menarik dan kurang diminati oleh konsumen.

Disisi lain juga dengan adanya ide kreatif dan inovatif akan berpengaruh terhadap omset pendapatan yangdiperoleh seorang pebisnis. Selain itu juga harus diperhatikan agar omset pendapatn tidak menurun dan produk yang dihasilkan tidak kalah saing antara lain dengan cara : Pertama, Kualitas produk yang menjamin baik sehingga seorang pebisnis tidak berfokus pada keuntungannya saja. Oleh karena itu sebelum memproduksi suatu produk sebaiknya memilih bahan dasar yang memiliki kualitas baik atau membandingkan antara bahan dasar satu dengan yang lain untuk mendapatkanyang terbaik dengan kualitas bagus yang ditampilkan. Kedua, selalu kreatif dalam menciptakan produk. Dengan adanya ide tersebut maka akan menjadi peuang bisnis yang laris dipasaran sehingga akan mendapatkan omset yang banyak. Salah satu cara dengan menyediakan produk yang dibutuhkan konsumen sesuai dengan trend sehingga konsumentidak merasa bosan. Ketiga, pelayanan kepada konsumen yang memuaskan. Dalam sistem pelayanan merupakan faktor utama dalam menarik minat yang dilakukan penjual terhadap pembeli. Ketika kita melayani konsumen dengan bersikap yang baik dan sopan maka konsumen merasa tidak tersinggung atas layanan yang diberikan. Karena ada pepatah yang mengatakan bahwapelanggan itu raja, oleh karena itu harus dilayani sehingga merasa puas dan ada keinginan untuk datang lagi. Keempat, memaksimalkan sistem media sosial sebagai sistem pemasaran. Dengan cara menggunakan media social makaseorang wirausaha dapat melakukan pemasaran yang tepat salah satunya dengan cara mengunggah foto produk sehingga akan berpeluang pembeli yang lebih luas.

Dalam berbisnis dengan memanfaatkan ide kreatif dan inovatif akan berdampak positif dalam berwirausaha. Namun juga berdampaknegatif dalam berbisnis jika tidak menggunakan kreatifitas dalammembuat suatu produk sehinnga konsumen merasa bosan dengan produk tersebut. Adapun dampak positif antara lain bisnis yang dijalankan akan berkembang dan berujung pada kesuksesan dan inovatif dalam perusahaan. Selain itu dengan memanfaatkan ide kreatif dan inovatif akan meningkatkan produktivitas dalam berbisnis. Produktivitas suatu pekerjaan sangat tergantung kepada kemauan untukbekerja lebih giat (Sukirman, 2017). Dengan memanfaatkan ide tersebut juga berdampak pada meningkatnya pendapatan seorang wirausaha yang mampu menghasilkan berbagai 
produk dengan model dan variasi baru yang dapat diaplikasikan dalam kewirausahaan serta mampu menarik para konsumen untuk membelinya. Tingkat kreatifitas dan inovatif akan membantudalam merespon perubahan yang terjadi di dunia bisnis yang penuh persaingan (Pandu, 2019). Semakin tinggi tingkat kreatif daninovatif seorang wirausaha maka akan berpengaruh terhadap perusahaan yang dijalankan seperti berkembangnya bisnis menjadi lebih unggul dari sebelumnya.Namun juga berdampak negatif jika tidak menggunakan ide kreatif dan inovatif dalam berbisnis. Karena tanpa adanya ide kreatif dan inovatif maka perusahaan yang dijalankan bisa kalah saing dengan perusahaan yang lainnya yang berujung mengalami kebangkrutan. Jika para pelaku usaha tidak memanfaatkan ide tersebut maka produk yang dihasilkan tidak mempunyai model terbaru sesuaidengan trend dalam zaman sekarang sehingga konsumen merasa bosan untuk membeli produk lagi. Oleh karena ituseorang wirausaha dalam membuat suatu produk sebaiknya mampu mencari strategi yang tepat dan unik agar tidak kalah saing dengan bisnis lainnya tanpa adanya pertentangan dengan ekonomi Islam.

\section{KESIMPULAN}

Berdasarkan kajian diatas maka diperoleh beberapa kesimpulan : (a) variabel kreatif dan inovatif dengan perspektif ekonomi Islam berpengaruh signifikan terhadap omset pendapatan dengan berbagai varian desain yang beragam dan minat daya beli konsumen akan meningkat, (b) variabel kualitas produk berpengaruh signifikan terhadap kepuasan konsumen yang menjadi keunggulan dalam berwirausaha. Variabel kualitas produk dan desain produk berpengaruh signifikan terhadap keputusan pembelian konsumen, dan (c) berdasarkan hasil pembahasan dapat disimpulkan bahwa tingkat kreatif dan inovatif tidak signifikan atau tidak membatasi mengenai jenis kelamin dan umur.

Adapun saran dari hasil penelitian ini yakni perlu adanya tindakan yang komprehensif yang didukung dengan adanya motivasi berwirausaha dengan jiwa kreatif dan inovatif dengan keberanian mengambil resiko. Dan juga adanya pengembangan usaha yang lebih efektif, sefisien sehingga terbentuknya usaha yang lebih maju dengan cara penerapan ekonomi Islam yang lebih baik lagi. 


\section{REFERENSI}

Kurniasari, R.D.. (2018). Pengaruh Inovasi, kreatvitas dan kualitas produk terhadap keunggulan bersaing. Yogyakarta. Jurnal eprints.uny.ac.id.

Suliyanto. (2012). Studi Kelayakan Bisnis. Jakarta: Salemba Empat.

Anwar, M. (2014). Pengantar Kewirausahaan Teori dan Aplikasi. Jakarta: Kencana. Alma, B. (2009). Kewirausahaan untuk Mahasiswa dan Umum. Bandung: Alfabeta.

Riansyah, R. (2017). Faktor Faktor yang Mempengaruhi Kreatifitas dan Inovasi serta Implikasinya. Jurnal Ilmiah Magister Manajemen, 2(1), 1-17.

Sukirman. (2017). Jiwa Kewirausahaan dan Nilai Kewirausahaan Meningkatkan kemandirian Usaha Melalui Perilaku Kewirausahaan. Jurnal Fakultas Ekonomi Universitas Muria, Volume 20 No 1.

Pandu, B.T. (2019). Prinsip dan Praktik Ekonomi Islam. Klaten: Cempaka Putih.

Dwi, P. (2020). Kewirausahaan Islami. Surakarta: CV. Djiwa Amarta Press. 